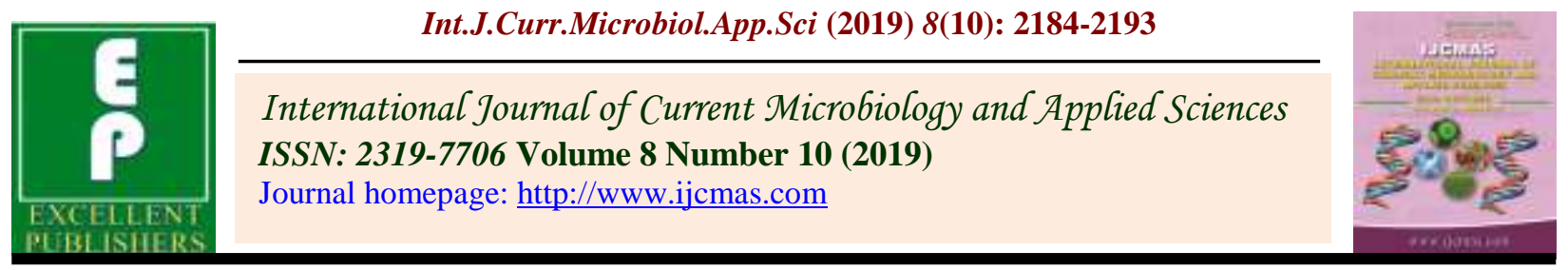

Original Research Article

https://doi.org/10.20546/ijcmas.2019.810.254

\title{
Optimization of Growth Conditions of Bacillus megaterium for Antifungal Activities against Cocoyam Phytopathogens
}

\author{
C. S. Mbajiuka*, V. C. Eze and V. O. Ifeanyi \\ Department of Microbiology, College of Natural Sciences, Michael Okpara University of \\ Agriculture, Umudike, Nigeria \\ *Corresponding author
}

Keywords

Cocoyam, Glucose,

Bacillus

megaterium,

Lactose, Pythium,

Rhizoctonia,

Fusarium

Article Info

Accepted:

17 September 2019

Available Online:

10 October 2019

\section{A B S T R A C T}

The biocontrol potential of Bacillus megaterium isolated from rhizosphere of turmeric plants was investigated in vitro against cocoyam pathogenic fungi. Antagonistic activity was examined under optimized $\mathrm{pH}(3.0,4.0,5.0,6.0,7.0$ and $8.0)$, carbon sources (glucose, xylose, sucrose and lactose), incubation period (24hrs, $48 \mathrm{hrs}, 72 \mathrm{hrs}, 96 \mathrm{hrs}$, and $120 \mathrm{hrs})$ and temperature $\left(20^{\circ} \mathrm{C}, 30^{\circ} \mathrm{C}, 40^{\circ} \mathrm{C}, 50^{\circ} \mathrm{C}\right.$, $60^{\circ} \mathrm{C}$ and $70^{\circ} \mathrm{C}$ ) for B. megaterium. Bacillus megaterium induced the presence of an inhibition halo, with values of $16.89 \pm 0.57 \mathrm{~mm}$ when tested in vitro against Fusarium spp. it also produced a zone of clearing of $13.57 \pm 0.57 \mathrm{~mm}$ against Aspergillus spp. The $B$. megaterium strain was greatly influenced by nutritional factors. Maximal antagonistic activity of the isolate was observed after 96h of incubation with over $18.0 \mathrm{~mm}$ zone of inhibition against Fusarium and $15.2 \mathrm{~mm}$ against Aspergillus species. Glucose and Lactose were found to be the ideal carbon source over xylose and sucrose for the growth of B. megaterium in the present work. In this present investigation, we have reported a soil-borne bacterium Bacillus megaterium which is antagonistic to cocoyam phytopathogens, and could make a substantial contribution to the prevention of spoilage of cocoyam.

\section{Introduction}

The human population has been predicted to rise to 9.2billion people in 2050 (Popp et al., 2013). Such a vast increase will result in substantial increase in demand for food supply. Tuber crops and overall crop yield have always been affected by phytopathogenic fungi. Fungal plant pathogens are accountable for large amounts of both pre- and postharvest food losses and in the absence of appropriate control measures, these losses would be expected to double (Glare et al., 2012).

In recent years, among the most important factors limiting production of different crops are soil-borne plant pathogens including fungi 
from genera Pythium, Rhizoctonia, Fusarium, Verticillium, Phytophthora spp, Sclerotinia, Sclerotium, and Rosellinia (Sosa et al., 2008). To contain this problem, several techniques have been devised as a means of controlling these pathogens (Parra and Ristaino, 2001). Among them include the use of cultural practices and chemical control using synthetic fungicides. Environmental pollution issues arising from the use of these synthetic chemicals with adverse consequences such as toxicity to humans as well as resistance of some pathogens to these fungicides has spurred the need for a better environmental friendly method of arresting these fungal pathogens (Hernández-Castillo et al., 2005). An alternative to reduce the effect of these plant pathogens is the use of antagonistic microorganisms such as: some species of the genus Bacillus which is recognized as one of the most effective biological control agent because of their properties on pathogens growth inhibition (Schisler et al., 2004; Sid et al., 2003).

Soil-borne bacteria that are antagonistic to plant pathogens could make a substantial contribution to prevention of plant diseases, and therefore represent an alternative to the use of chemical pesticides in agriculture (Walsh et al., 2001). Due to their role in plant health and soil fertility, soil and the rhizosphere have frequently been used as a model environment for screening of putative agents for use in biological control of soilborne plant pathogens.

Cocoyam (Colocasia esculentus) is one of the important crops in Nigeria. Nigeria leads its production with 3.7 million tonnes (MT) per annum. Current yield levels of the cocoyam production are low on a worldwide basis.

An appraisal of the major constraints on cocoyam production indicated that it is not due to lack of demand but losses due to field and especially post-harvest deterioration (Nwachukwu and Osuji 2008). Management of postharvest diseases using microbial antagonists, natural plant-derived products and compounds that are generally recognized as safe has been demonstrated to be most suitable to replace the synthetic fungicides, which are either being banned or recommended for limited use (Sharma et al., 2009; Talibi et al., 2014).

The bacteria of the genus Bacillus have a great potential as a biological control agent because they keep their viability with long-term storage (Nagorska et al., 2007; Ongena and Jacques 2008).

Biosynthesis of antibiotics from microorganisms is often regulated by nutritional and environmental factors. ElBanna (2006) reported that antimicrobial substances produced by bacterial species were greatly influenced by variation of carbon sources.

Several abiotic factors, such as $\mathrm{pH}$ and temperature, have been identified as having an influence on antibiotic production from bacteria. Antifungal peptides produced by Bacillus species include mycobacillins, surfactins, mycosubtilins, and fungistatins (Sadfi et al., 2001). It can produce a wide range of other metabolites, including chitinases and other cell wall-degrading enzymes, volatiles, and compounds that elicit plant resistance mechanisms (Sadfi et al., 2001). Volatile metabolites produced from Bacillus sp. have been reported to inhibit mycelia growth of Fusarium oxysporum.

This study was therefore aimed at isolating, characterizing and identifying Bacillus species from the rhizosphere soil of turmeric plant with antifungal potentials against cocoyam phytopathogens as well as to carry out optimization studies on the best conditions 
necessary for antifungal activities of Bacillus species with very high antifungal potentials.

\section{Materials and Methods}

Soil samples were randomly collected from the rhizoshperic portions of turmeric plants. All samples were carefully collected by scraping the soil surface with a sterile scoop and were transferred to the laboratory in sterilized polyethylene bags.

One gram of each soil sample was suspended in $9 \mathrm{ml}$ of sterile distilled water to obtain an appropriate dilution and plated on nutrient agar (NA) modified with 3\% glycerol to become glycerol modified nutrient agar (GMNA) at $30^{\circ} \mathrm{C}$ for 48 hours. Once there was establishment of growth, subcultures were made from different distinct colonies based on morphological differences to obtain pure cultures of the different isolates. The isolated bacterial strains were stored in agar slants for further study.

\section{Pathogenicity Test}

The deliberate infestation Techniques (DIT) described by Alimi et al., (2012) was adopted. Healthy cocoyam corns were surface disinfected and with the aid of a flamed $5 \mathrm{~mm}$ cork borer, holes were bored on the corm flesh and discs cuts of each isolate taken from 48hours old culture were put inside the bored hole and covered with the removed flesh. The point of infection was sealed with sterile paraffin. The inoculated corms were incubated for 10-14days. They were observed for signs of rot including softening, dry-up, discoloration, exudates and offensive odours.

After incubation, the corms were cut open along the line of inoculation and isolation was made again. Organisms which caused rots measuring 7 to $10 \mathrm{~mm}$ were considered as pathogenic.

\section{Screening on fungicidal activities of bacillus species on cocoyam phytopathogens}

This was done according to the methods stated by Aboy-Aly (2008). Each Bacillus isolates was cultured in nutrient broth for 48hours at room temperature. The culture broths were centrifuged at $3000 \mathrm{rpm}$ for 10 to 15 minutes. The residue (bacterial cells) were then diluted to the $4^{\text {th }}$ diluent to give a suspension of about $1 \mathrm{x} 10^{8} / \mathrm{ml}$ with optical density of 0.45 at $610 \mathrm{~nm}$ wavelength as described by Haripras and Niranjana (2008). The suspensions were used in the agar well diffusion techniques. Shallow narrow wells were bored at distance of $2 \mathrm{~cm}$ from the edge of the Petri dish and opposite sides of the plates.

One $\mathrm{ml}$ of the bacterial suspension was poured into the wells bored on the surface of sterile nutrient agar plates. After 24 hours, the plates were floored with $1 \mathrm{ml}$ of a 48 hours broth culture of test organisms (cocoyam phytopathogens) and incubated at $30^{\circ} \mathrm{C}$ for 5 days.

The presence of clear zone around the wells containing Bacillus isolates was indicative of a positive antifungal activity against the cocoyam pathogen.

\section{Optimization of the Bacillus isolate for antifungal activity}

In order to investigate the best conditions for antifungal activities of the selected Bacillus isolate, the role of different environmental factors such as carbon source, $\mathrm{pH}$, temperature, incubation time were determined. This method below follows the early findings of Awais (2007).

Nutrient media adjusted to varying $\mathrm{pH}$ (3.0, 4.0, 5.0, 6.0, 7.0 and 8.0) using different buffers were inoculated with $0.1 \mathrm{ml}$ of overnight broth culture of test organism and 
incubated at $30^{\circ} \mathrm{C}$ and the antifungal activity was determined using the agar well diffusion method. Similarly, test tubes containing $10 \mathrm{ml}$ of nutrient broth were each inoculated with $0.1 \mathrm{ml}$ of overnight culture of the test organism. Incubation was done at $20^{\circ} \mathrm{C}, 30^{\circ} \mathrm{C}$, $40^{\circ} \mathrm{C}, 50^{\circ} \mathrm{C}, \quad 60^{\circ} \mathrm{C}$ and $70^{\circ} \mathrm{C}$ in order to determine the optimal temperature for the antifungal activity of Bacillus isolate. After 24hours, the antifungal activity was determined using agar well diffusion method. Antifungal activities were also evaluated after 24hrs, 48hrs, 72hrs, 96hrs, and $120 \mathrm{hrs}$ of incubation.

Equally, different carbon sources (1\% glucose, $1 \%$ xylose, $1 \%$ sucrose and $1 \%$ lactose) were separately added into a basal medium containing $5 \% \mathrm{NaCl}, 2 \%$ tryptone, $0.15 \%$ $\mathrm{MgSO}_{4}, 0.15 \% \quad \mathrm{~K}_{2} \mathrm{HPO}_{4}$ and $3 \%$ glycerol. They were inoculated with $0.1 \mathrm{ml}$ of an overnight broth culture of the test organisms and incubated for $24 \mathrm{hrs}$ at $30^{\circ} \mathrm{C}$ with an initial $\mathrm{pH}$ of 6.5. The antifungal activity was determined using agar well diffusion method described earlier.

\section{Results and Discussion}

The results of antagonistic potentials of Bacillus megaterium strains on the growth (in vitro) of different fungal pathogens of cocoyam are shown in table 1. Bacillus megaterium and $B$. subtilis induced an inhibition halo of $15.66 \mathrm{~mm}$ and $13.33 \mathrm{~mm}$ respectively on Aspergillus species; $16.89 \mathrm{~mm}$ and $16.26 \mathrm{~mm}$ on Fusarium species. Bacillus megaterium had a higher antagonistic activity than the other species with a diameter zone of inhibition of $13.57 \mathrm{~mm}$ against Penicillium species. The highest inhibition halos produced by $B$. megaterium and $B$. subtilis against Fusarium species were observed to be significantly different from each other $(p<0.05)$. The findings of this study were also in agreement with the reports of Madhaiyan et al., (2010) and Zhang et al., (2012), who found that strains of $B$. methylotrophicus have a high antagonistic activity against a wide diversity of phytopathogens fungi. Kumar et al., (2012) reported the antagonistic activity of Bacillus strain, which strongly inhibited the growth of several phytopathogens such as Macrophomina phaseolina, Fusarium oxysporum, F. solani, Sclerotinia sclerotiorum, Rhizoctonia solani and Colletotricum sp. in vitro.

In this study, the in vitro inhibition of the growth of the phytopathogens by $\mathrm{B}$. megaterium seems to indicate that cell wall hydrolytic enzymes might be responsible for the inhibitory activity (cell lysis). Production of extracellular enzymes by biocontrol bacteria is a well-documented phenomenon that is thought to be involved in lysis of the cell wall of phytopathogenic fungi (Kumar et al., 2012; Kuddus and Ahmad, 2013). Among Bacillus spp., B. subtilis and occasionally, $B$. megaterium, B. cereus, $B$. pumilus and $B$. polymixa have been studied as biocontrol agents. In this respect, microbial bio-control agents have shown a great potential as an alternative to synthetic fungicides and offer an environmentally friendly alternative to the use of synthetic pesticides (Kotan et al., 2009). The degradation of fungal cell walls with the production of hydrolytic enzymes of bacterial isolates has been described as one of the most important mechanisms for biocontrol of phytopathogenic fungi (Weller 2007; Elshafie et al., 2012). An optimum $\mathrm{pH}$ (5-7 as was observed in this study) promoted cell growth and it can thus be seen that $\mathrm{pH}$ plays a key role in enzyme production for enhanced antagonistic activity. Earlier studies reported that near-neutral $\mathrm{pH}$ is suitable for the production of antagonistic substances (Shanmugaiah et al., 2008). The B. megaterium strain was greatly influenced by nutritional factors. 
Table.1 Antifungal activities of Bacillus isolates on the cocoyam pathogens (zone of inhibition $(\mathrm{mm})$

\begin{tabular}{|c|c|c|c|}
\hline \multirow{2}{*}{ Bacillus Isolates } & \multicolumn{3}{|c|}{ Cocoyam pathogens } \\
\cline { 2 - 4 } & $\begin{array}{c}\text { Aspergillus } \\
\text { Species }\end{array}$ & $\begin{array}{c}\text { Penicillium } \\
\text { Species }\end{array}$ & $\begin{array}{c}\text { Fusarium } \\
\text { Species }\end{array}$ \\
\hline Bacillus subtilis & $13.33 \pm 0.57^{\mathrm{c}}$ & $8.66 \pm 0.57^{\mathrm{a}}$ & $16.26 \pm 0.57^{\mathrm{c}}$ \\
\hline Bacillus licheniforms & $11.33 \pm 0.57^{\mathrm{b}}$ & $11.33 \pm 0.57^{\mathrm{bc}}$ & $12.33 \pm 0.57^{\mathrm{b}}$ \\
\hline Bacillus megaterium & $15.66 \pm 0.57^{\mathrm{d}}$ & $13.57 \pm 0.57^{\mathrm{c}}$ & $16.89 \pm 0.57^{\mathrm{b}}$ \\
\hline Bacillus thuringensis & $7.33 \pm 0.57^{\mathrm{a}}$ & $7.66 \pm 0.57^{\mathrm{a}}$ & $9.66 \pm 0.57^{\mathrm{a}}$ \\
\hline Bacillus cereus & $10.33+0.57^{\mathrm{b}}$ & $10.66 \pm 0.57^{\mathrm{b}}$ & $13.66+0.57^{\mathrm{b}}$ \\
\hline $\begin{array}{c}\text { Ketoconazole } \\
\text { (Control) }\end{array}$ & $24.00+0.57^{\mathrm{e}}$ & $22.66 \pm 0.57^{\mathrm{d}}$ & $25.66 \pm 0.57^{\mathrm{d}}$ \\
\hline
\end{tabular}

Values are the mean \pm standard deviation of two replication of each parameter. Values with different superscript down a column are significantly different from each other.

Fig.1 Effects of different temperature on the antifungal activities of Bacillus megaterium

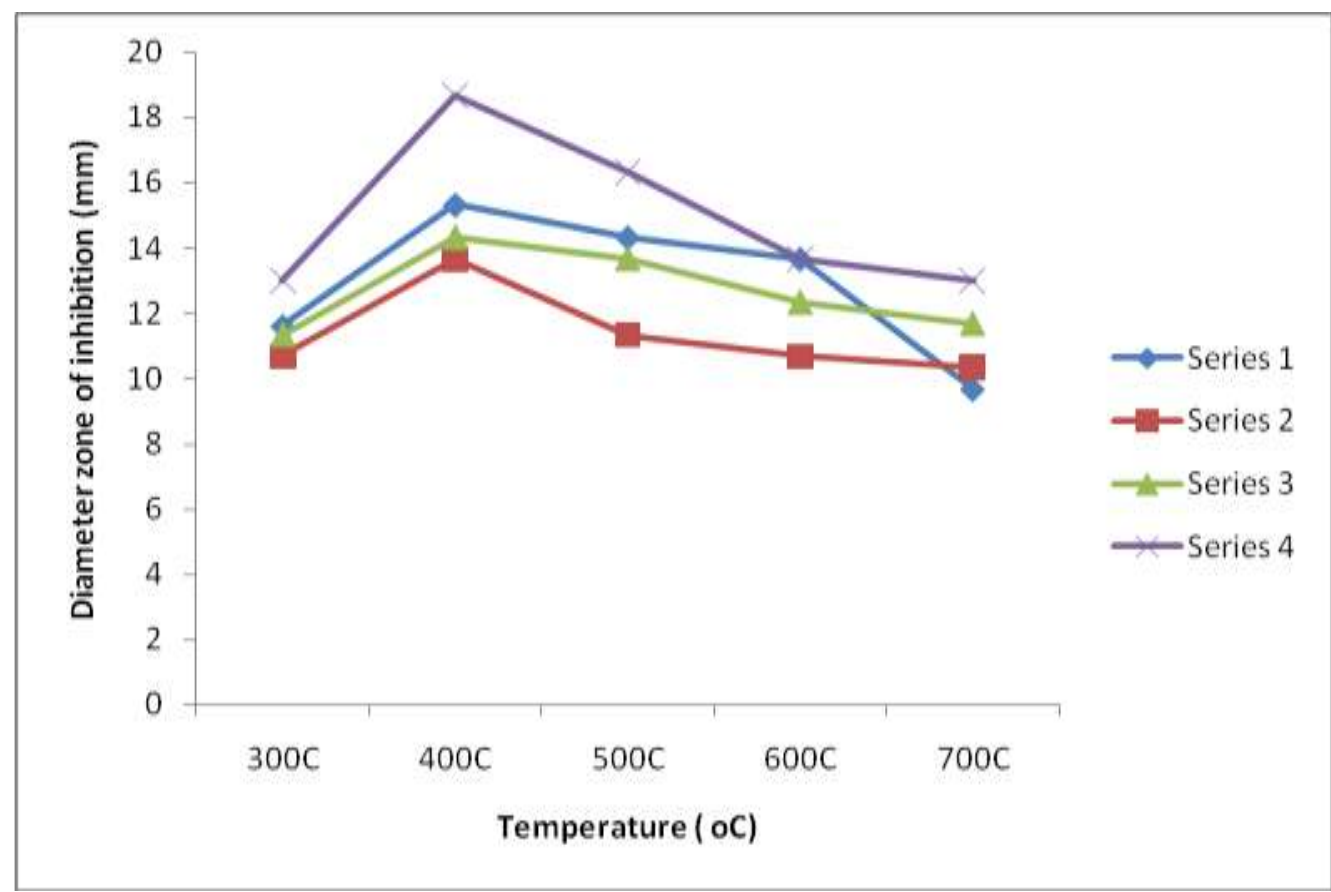

Keys: $\quad$ Series $1=$ Aspergillus species; Series $2=$ Penicillium species

Series 3 = Rhizopus species; Series $4=$ Fusarium species 
Fig.2 Effects of Incubation time on the antifungal activities of Bacillus megaterium

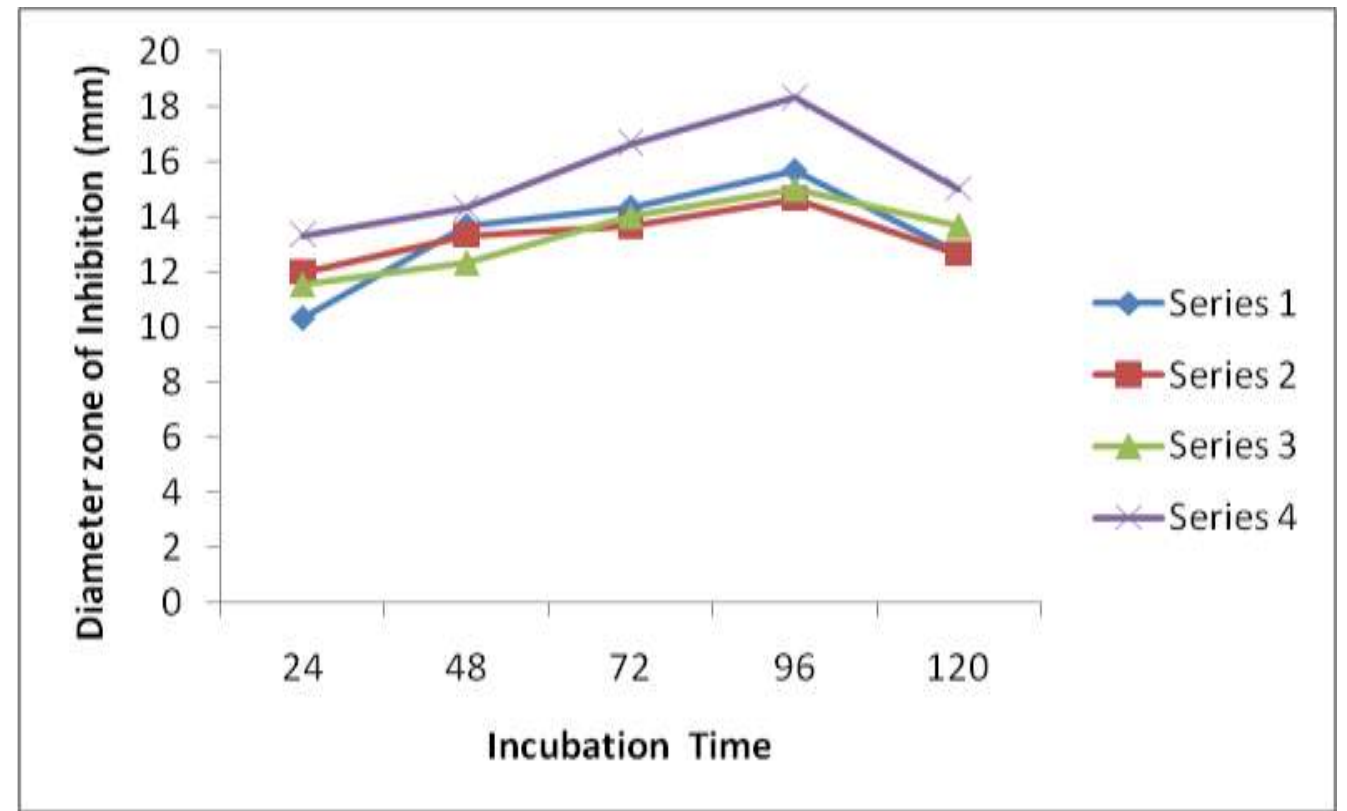

Keys :-Series 1 = Aspergillus species; Series $2=$ Penicillium species; Series $3=$ Rhizopus species; Series $4=$ Fusarium species

Fig.3 Effects of different carbon sources on antifungal activities of Bacillus megaterium

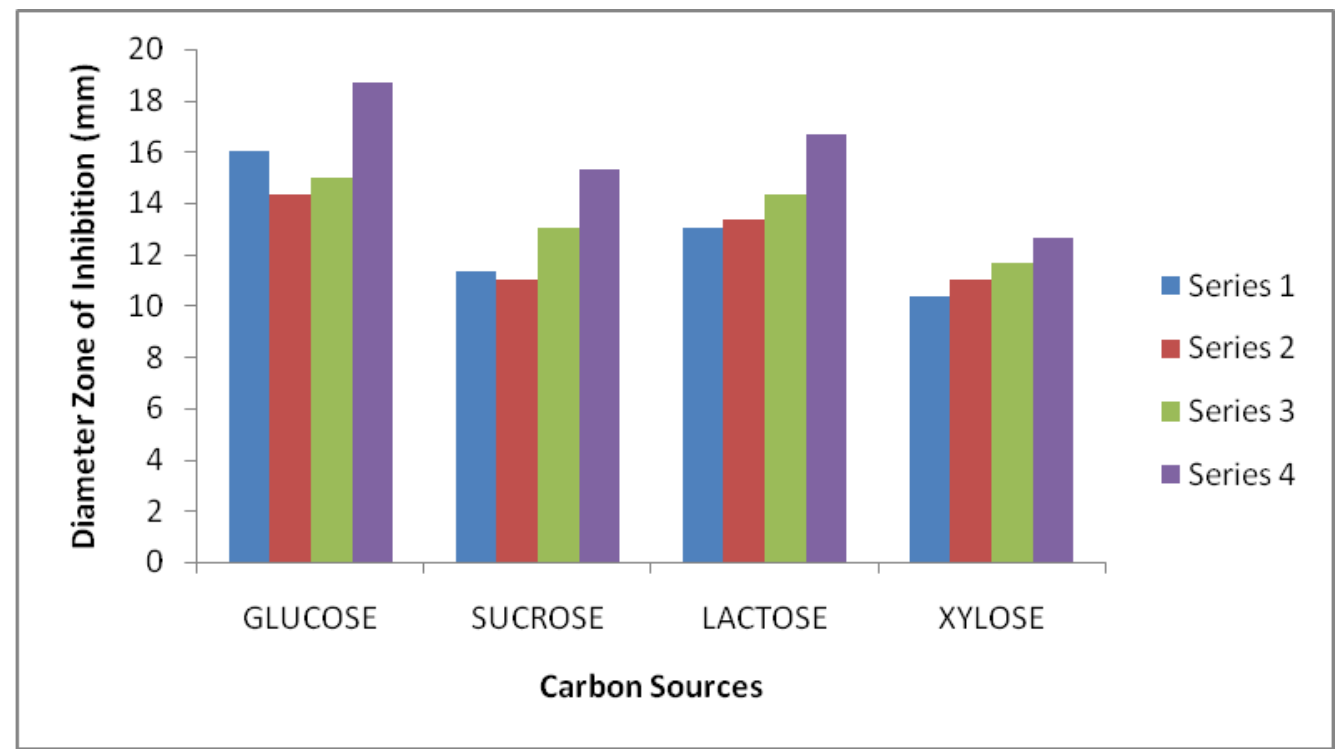

Keys: Series 1=Aspergillus species; Series 2=Penicillium species Series 3 = Rhizopus species; Series 4=Fusarium species 
Fig.4 Effects of $\mathrm{pH}$ on the antifungal activities of Bacillus megaterium

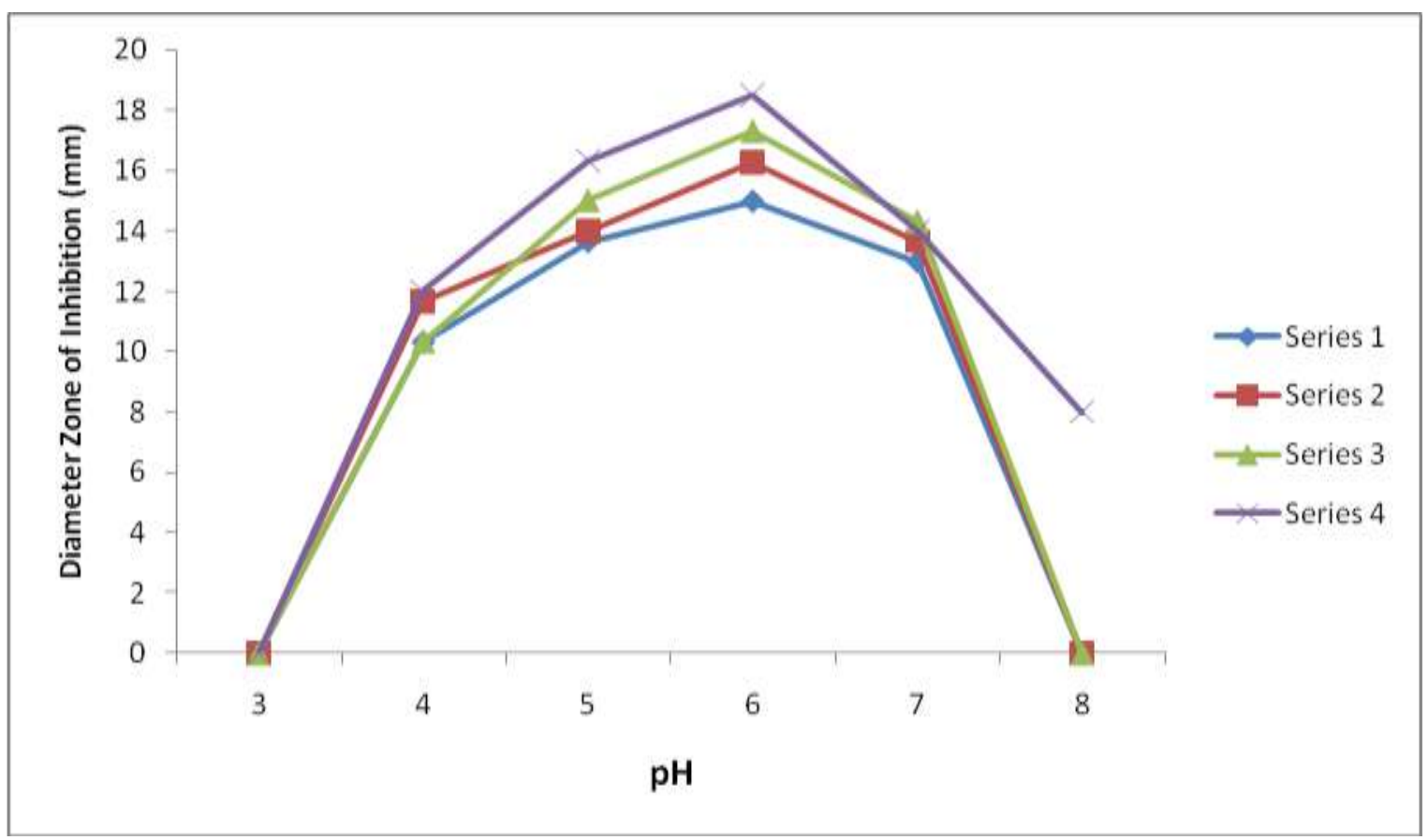

Keys: Series $1=$ Aspergillus species; Series $2=$ Penicillium species

Series $3=$ Rhizopus species; Series $4=$ Fusarium species

This finding is consistent with earlier reports for B. megaterium, B. subtilis, B. circulans and $B$. cepacia strains showing that the production of antibacterial and antifungal substances and secondary metabolites in potent organisms was greatly influenced by carbon source (El-Banna, 2006; El-Banna and Qaddoumi, 2016).

It was observed that maximal antagonistic activity of the isolate was after $96 \mathrm{~h}$ of incubation (Fig 4.4) with over 18.0mm zone of inhibition against Fusarium and $15.2 \mathrm{~mm}$ against Aspergillus species. The incubation period seemed to be ideal for industrial production of biocidal product.

The present study was comparable with that of Nalisha et al., (2006) who observed maximum growth of $B$. subtilis at $36 \mathrm{hrs}$ of incubation as in the present study. Okanlawon et al., (2010) found highest growth at $48 \mathrm{hrs}$ for most of the isolates in their study. Prescott et al., (2005) and Ynte et al., (2004) observed B. cereus was able to grow between 18 to $48 \mathrm{hrs}$.

Glucose and Lactose were found to be the ideal carbon source over xylose and sucrose for the growth of $B$. megaterium in the present work. Results of this study are consistent with those of previous studies, where different carbon source had a significant influence on the growth of B. subtilis and the highest levels of growth inhibition occurred in the presence of (2\%) glucose (De Sarrau et al., 2012, Singh et al., 2013). Usama (2003) observed lactose as the ideal carbon source in a previous study. Mizumoto et al., 2007 showed addition of glucose as carbon source in minimal salt medium containing Okra enhanced the bioactive iturin A production in solid state fermentation (SSF) by B. subtilis RB14-CS. Joshi et al., (2008) observed glucose in minimal salt media enhanced the production of lichenysin by $B$. licheniformis. Usama (2003) tested several carbon sources reported 
that the maximum growth of $B$. subtilis and $\beta$ glucanase production was obtained with lactose as sole carbon source.

In the present investigation, $38^{\circ} \mathrm{C}$ was found to be ideal for the growth of $B$. megaterium. Hence these bacteria and their products seem to be ideal for the prevailing conditions in most part of the soil. Okanlawon et al., 2010 observed optimum growth of $B$. cereus at $37^{\circ} \mathrm{C}$. Another $B$. subtilis strain, showed optimum temperature for the production of antifungal substance at $30^{\circ} \mathrm{C}$ in liquid cultivation, but at below $25^{\circ} \mathrm{C}$ in solid state cultivation (Ohno et al., 1995).

The use of $B$. megaterium as a biocontrol agent against cocoyam pathogens may be an economically viable way of suppressing postharvest rot. The spore forming ability of this organism and the vast array of antimicrobial compounds it can produce make it a valid candidate for biocontrol.

\section{References}

De Sarrau, B., Clavel, T., Clerté, C., Carlin, F. and Giniès, C. (2012). Influence of anaerobiosis and low temperature on Bacillus cereus growth, metabolism, and membrane properties. Appl Environ Microbiol., 78: 1715-1723.

El-Banna, N. and Qaddoumi, S.S. (2016). Antimicrobial activity of Bacillus cereus: Isolation, identification and the effect of carbon and nitrogen source on its antagonistic activity. J. Microbiol Antimicrob., 8:7-13.

El-Banna, N.M. (2006). Effect of carbon source on the antimicrobial activity of Corynebactirum kutscheri and Corynebactrium xecroris. Afr $J$ Biotechnol., 5:833-5.

Glare, T., Caradus, J., Gelernter, W., Jackson, T., Keyhani, N., Kohl, J., Marrone, P., Morin, L. and Stewart, A. (2012).
Have biopesticides come of age? Trends Microbiol. 30:250-258.

Hernández-Castillo, F.D., Carvajal, C.R., Guerrero, E., Sánchez, A., Gallegos, G. and Lira-Saldivar, R.H. (2005). Susceptibilidad a fungicidas de grupos de anastomosis del hongo Rhizoctonia solani Khün colectados en zonas paperas de Chihuahua, México. International Journal of Experimental Botany, 74(1):259-269.

Joshi, R.H., Dodia, M.S. and Singh, S.P. (2008). Production and optimization of a commercially viable alkaline protease from a haloalkaliphilic bacterium. Biotechnol. Bioprocess Eng., 13: 552-559.

Kuddus, M. and Ahmad, I.Z. (2013). Isolation of novel chitinolytic bacteria and production optimization of extracellular chitinase. J Genet Eng Biotechnol., 11:39-46.

Kumar, P., Dubey, R.C. and Maheshwari, D.K. (2012). Bacillus strains isolated from rhizosphere showed plant growth promoting and antagonistic activity against phytopathogens. Microbiological Research, 167(8), 493-499.

Mizumoto, S., Hirai, M. and Shoda, M. (2007). Enhanced iturin A production by Bacillus subtilis and its effect on suppression of the plant pathogen Rhizoctonia solani. Appl. Microbiol. Biotechnol., 75: 1267-1274.

Nagorska, K., Bikowski, M. and Obuchowskji, M. (2007). Multicellular behaviour and production of a wide variety of toxic substances support usage of Bacillus subtilis as a powerful biocontrol agent. Acta Biochimica Polonica, 54: 495- 508.

Nalisha, I., Muskhazli, M. and Farizan, T. (2006). Production of Bioactive Compounds by Bacillus subtilis against Sclerotium rolfsii. Malaysian 
Journal of Microbiology, 2(2):19-23.

Ohno, A., Ano, T. and Shoda, M. (1995). Effect of temperature on production of lipopeptide antibiotics iturin $\mathrm{A}$ and surfactin in a dual producer, Bacillus subtilis RB14, in solid state fermentation., J. Ferment. Bioengg., 80: 517-519.

Okanlawon, B.M., Ogunbanwo, S.T. and Okunlola, A.O. (2010). Growth of Bacillus cereus isolated from some traditional condiments under different regimens. Afr. J. Biotechnol., 8(14): 2129-2135.

Ongena, M. and Jacques, P. (2008). Bacillus lipopeptides: versatile weapons for plant disease biocontrol. Trends in Microbiology, 16: 115-125.

Parra, G. and Ristaino, J. (2001). Resistance to Mefenoxam and Metalaxyl among field isolates of Phytophthora capsici causing Phytophthora Blight of bell pepper. Plant Disease, 85(10):10691075.

Popp, J., Pet, K. and Nagy, J. (2013). Pesticide productivity and food security. A review. Agron. Sustain. Dev. 33:243255.

Prescott, L.M., Harley, P.J. and Klein, A.D. (2005). General Microbiology. 6th ed. McGraw-Hill Companies, Inc., New York, USA, p 951.

Sadfi, N., Chérif. M., Fliss, I., Boudabbous, A. and Antoun, H. (2001). Evaluation of bacterial isolates from salty soils and Bacillus thuringiensis strains for the biocontrol of Fusarium dry rot of potato tubers. J Plant Pathol., 83:10118.

Schisler, D.A., Slininger, P.J., Behle, R.W. and Jackson, M.A. (2004). Formulation of Bacillus spp. for biological control of plant diseases. Phytopathology, 94(11):1267-1271.

Shanmugaiah, V., Mathivanan, N. and Balasubramanian, N. (2008).
Optimization of cultural conditions for production of chitinase by Bacillus laterosporous MML2270 isolated from rice rhizosphere soil. Afr J Biotechnol., 7:2562-68.

Sharma R.R., Singh D., Singh R. (2009): Biological control of postharvest diseases of fruits and vegetables by microbial antagonists: a review. Biological Control, 50: 205-221.

Sid, A.A., Ezziyyani, M., Pérez-Sanchez, C. and Candela, M.E. (2003). Effect of chitin on biological control activity of Bacillus spp. and Trichoderma harzianum against root rot disease in pepper (Capsicum annuum) plants. European Journal of Plant Pathology, 109(6):633-637.

Singh, P., Shera, S.S., Banik, J. and Banik, R. (2013). Optimization of cultural conditions using response surface methodology versus artificial neural network and modeling of Lglutaminase production by Bacillus cereus MTCC 1305. Bioresour Technol 137:261-269.

Sosa, A., Baro, Y. and Gonzales, M. (2008). Aislamiento, identificación y caracterización de cepas de Bacillus spp. Con potencialidades para el control biológico de los generous Rhizoctonia, Sclerotium y Pythium. Taller Latinoamericano de Biocontrol de Fitopatógenos, 2, Ciudad de La Habana, Cuba, 14(1):63-69.

Talibi I., Boubaker H., Boudyach E.H., Ait Ben Aoumar A. (2014): Alternative methods for the control of postharvest citrus diseases. Journal of Applied Microbiology, 117: 1-17.

Usama, B., Hesham, E.E., Ismail, I.M., Hassan, M., Ewa, W. and Sawsan, A.E. (2003). $\beta$-glucanase production from genetically modified recombinant Escherichia coli: Effect of growth substrates and development of a 
culture medium in shake flask and stirred tank bioreactor. Process Biochem., 39:307- 313.

Walsh, U.F., Morrissey, J.P. and O'Gara, F. (2001). Pseudomonas for biocontrol of phytopathogens: from functional genomics to commercial exploitation. Curr Opin Biotechnol., 12:289-95

Ynte, P.D., Vries, L.M., Hornstra, W.M. and Tjakko, A.D. (2004). Growth and sporulation of Bacillus cereus ATCC
14579 under defined conditions: Temporal expression of genes for key sigma factors. Appl. Environ. Microbiol., 70(4): 2514-2519.

Zhang, Y., Jiang, L., Ren, F., Yang, J. and Guo, H. (2012). Response surface methodology analysis to improve production of tyrothricin in Bacillus brevis. African Journal of Biotechnology, 11(47): 10744-10752.

\section{How to cite this article:}

Mbajiuka, C. S., V. C. Eze and Ifeanyi, V. O. 2019. Optimization of Growth Conditions of Bacillus megaterium for Antifungal Activities against Cocoyam Phytopathogens. Int.J.Curr.Microbiol.App.Sci. 8(10): 2184-2193. doi: https://doi.org/10.20546/ijcmas.2019.810.254 